\title{
Development and Organization of the Evolutionarily Conserved Three-Layered Olfactory Cortex
}

\author{
Esther Klingler
}

DOI:http://dx.doi.org/10.1523/ENEURO.0193-16.2016

Department of Basic Neuroscience, University of Geneva, 1211 Geneva 4, Switzerland

\begin{abstract}
The olfactory cortex is part of the mammalian cerebral cortex together with the neocortex and the hippocampus. It receives direct input from the olfactory bulbs and participates in odor discrimination, association, and learning (Bekkers and Suzuki, 2013). It is thought to be an evolutionarily conserved paleocortex, which shares common characteristics with the three-layered general cortex of reptiles (Aboitiz et al., 2002). The olfactory cortex has been studied as a "simple model" to address sensory processing, though little is known about its precise cell origin, diversity, and identity. While the development and the cellular diversity of the six-layered neocortex are increasingly understood, the olfactory cortex remains poorly documented in these aspects. Here is a review of current knowledge of the development and organization of the olfactory cortex, keeping the analogy with those of the neocortex. The comparison of olfactory cortex and neocortex will allow the opening of evolutionary perspectives on cortical development.
\end{abstract}

Key words: cell identity; cortical layers; migration; neocortex; neurogenesis; olfactory cortex

\section{Significance Statement}

The olfactory cortex is an evolutionarily conserved paleocortex implicated in odor processing. While several studies addressed how the olfactory cortex encodes and processes odorant information, little is known about its precise cellular origin, diversity, and identity. Unraveling where the cells are born and how they migrate toward and settle the olfactory cortex during development is of main importance in understanding its circuit organization and function. In addition, comparing the development of the olfactory cortex with that of the neocortex will help in identifying common evolutionarily conserved developmental mechanisms as well as new mechanisms specific to the neocortex that appeared later during evolution and participate in building the mammalian cortex.

\section{Introduction}

Mammalian cerebral cortex comprises the neocortex, the hippocampus, and the olfactory cortex. The olfactory

Received July 6, 2016; accepted December 8, 2016; First published January 20, 2017.

The author declares no competing financial interests.

Author contributions: E.K. designed research; E.K. wrote the paper.

This work was supported by University of Geneva (Geneva, Switzerland).

Acknowledgments: I thank A. Hay, G. Limoni, and U. Tomasello for constructive comments and corrections on the manuscript. I also thank L. Goutebroze and D. Jabaudon for their support.

Correspondence should be addressed to Esther Klingler, Jabaudon Laboratory, Department of Basic Neuroscience, University of Geneva, CMU, 1, rue Michel Servet, 1211 Geneva 4, Switzerland. E-mail: esther.klingler@unige.ch. cortex is an evolutionarily conserved paleocortex located in the ventrolateral part of the telencephalon and shares common characteristics with the general cortex of reptiles, which are composed of three thin layers (Aboitiz et al., 2002; Shepherd, 2011; Fournier et al., 2015). This three-layered organization, also called allocortex, is conserved in both the hippocampus (medial pallium derivative) and the olfactory cortex (lateral pallium derivative; Aboitiz et al., 2002). The mammalian olfactory cortex is

DOI:http://dx.doi.org/10.1523/ENEURO.0193-16.2016 Copyright () 2017 Klingler

This is an open-access article distributed under the terms of the Creative Commons Attribution 4.0 International, which permits unrestricted use, distribution and reproduction in any medium provided that the original work is properly attributed. 
subdivided into several structures along anteroposterior axis, as follows: the anterior olfactory nucleus, the olfactory tubercle, the piriform cortex, the olfactory amygdala [cortical amygdala and nucleus of the lateral olfactory tract (LOT)], and the lateral entorhinal cortex (IENT; Haberly, 2001; Brunjes et al., 2005; Sanchez-Andrade and Kendrick, 2009). In contrast to the classic sensory pathway where sensory information is first relayed in the thalamus before reaching the neocortex, the olfactory cortex receives direct sensory inputs from the mitral and tufted cells of olfactory bulb (OB) via the LOT, and is thought to play a key role in olfaction (Wilson and Mainen, 2006; Isaacson, 2010; Leinwand and Chalasani, 2011; Bekkers and Suzuki, 2013). The piriform cortex is the most studied structure of the olfactory cortex. It receives inputs from the $\mathrm{OB}$, as well as from the other regions of the olfactory cortex cited above, and sends projections to the anterior olfactory nucleus, the olfactory tubercle, the cortical amygdala (CoA), and the IENT within the olfactory cortex, as well as to the mediodorsal nucleus of the thalamus and to several subdivisions of the prefrontal cortex [including the infralimbic (IL), orbitofrontal, and agranual insular cortices; Johnson et al., 2000; Ekstrand et al., 2001; Meyer et al., 2006; Kerr et al., 2007]. Finally, the piriform cortex sends consequent feedback projections to the OB (Haberly and Price, 1978; Shipley and Adamek, 1984). The piriform cortex has been shown to participate in odor discrimination, association, and learning (Bekkers and Suzuki, 2013); it allows object recognition in a sensory landscape, whose relevant perceptual dimensions are dynamically shaped by sensory experience (Fournier et al., 2015).

While the development of the six-layered neocortex has been extensively described, the development of the olfactory cortex remains poorly understood. Neurons of the olfactory cortex seem to have multiple origins both in the pallial and the subpallial ventricular zones (VZs; Carney et al., 2006; Garcia-Moreno et al., 2008). Moreover, these neurons migrate over long distances and display complex migratory properties before reaching their final destination in the olfactory cortex and organizing into three layers. In this review, we discuss current knowledge on the development and organization of the olfactory cortex and investigate the following questions. How is the olfactory cortex specified during development? Where are the olfactory cortex neurons born? How do they migrate to the olfactory cortex and form the three layers? What is known about neuron diversity within the olfactory cortex, and how do they encode olfactory information? These questions will be addressed keeping the analogy with the neocortex development in order to open evolutionary perspectives on cortical development.

\section{Arealization and neurogenesis}

During the first 10 days of mouse embryonic development, the pallial neuroepithelium proliferates, allowing the exponential generation of progenies through symmetric divisions in the VZ (Noctor et al., 2004). From embryonic day 11 (E11), the first postmitotic neurons are produced by asymmetric divisions, generating both progenies, which stay in the VZ, and neuroblasts, which migrate out of the VZ toward the cortical surface.

\section{Arealization of the cortex by signaling centers}

Based on gene expression, the pallium is subdivided into four major subregions, namely the medial, dorsal, lateral, and ventral pallium; each pallial region is thought to give rise to specific cortical structures, such as the hippocampus, the neocortex, the olfactory cortex, and the amygdala/endopiriform cortex nuclei, respectively (Puelles et al., 2000; Yun et al., 2001). Intrinsic mechanisms based on morphogens and signaling molecules secreted by patterning centers allow the graded expression of transcription factors by cortical progenitors and the development of the different cortical fields (O'Leary et al., 2007; Arai and Pierani, 2014). The following three patterning centers lie at the borders of the telencephalon and participate in the arealization of the cortex: the cortical hem (between cortical and choroidal fields); the commissural plate (at the rostromedial pole of the telencephalon); and the cortical antihem (at the pallial-subpallial boundary, PSB; Mallamaci and Stoykova, 2006). The LIM homeobox protein 2 (LHX2), expressed in a rostrolateral ${ }^{\mathrm{HIGH}}$ to caudomedial ${ }^{\text {LOW }}$ gradient, suppresses hem and antihem fates, both of which expanded in Lhx2 mutant mice (Bulchand et al., 2001; Monuki et al., 2001; Nakagawa and O'Leary, 2001; Mangale et al., 2008). The transcription factor FOXG1, expressed in a rostrolateral ${ }^{\mathrm{HIGH}}$ to caudomedial $^{\text {LOW }}$ gradient, suppresses hem fate and is required for lateral fates, including that of the antihem (Dou et al., 1999; Muzio and Mallamaci, 2005; Hanashima et al., 2007; Shibata et al., 2008). The cortical antihem is of major importance for the specification of the olfactory cortex. In the following section, we will discuss the antihem specification and functions during development (see O'Leary et al., 2007; Subramanian et al., 2009; Montiel and Aboitiz, 2015 for further information about organizing centers and arealization of the cerebral cortex).

\section{The antihem, major signaling center for the determination of the olfactory cortex}

The antihem is located at the PSB, between the ventral pallium and the dorsal lateral ganglionic eminence (dLGE; Yun et al., 2001). The antihem is delineated from adjacent regions through the exclusive expression of the transcription factor $D b \times 1$ in the ventral pallium VZ, as well as the enriched expression of the secreted Frizzled related gene sFrp2 (Kim et al., 2001; Yun et al., 2001; Assimacopoulos et al., 2003; Medina et al., 2004). The ventral pallium and the adjacent dLGE both display an enriched expression of Pax6 transcription factor, which is required for the development of lateral and ventral pallial identities (olfactory cortex and amygdaloid complex; Stoykova et al., 1996; Toresson et al., 2000; Kim et al., 2001; Yun et al., 2001; Hirata et al., 2002; Tole, 2005; Piñon et al., 2008; Cocas et al., 2011).

The position and the specification of the antihem rely on the expression of transcription factors Pax6, T/x, and Gsh2. In Pax6 mutant mice, the ventral and the lateral pallium ectopically express subpallial markers, such as Mash1, Gsh2, and Dlx2 (Stoykova et al., 1996, 1997, 
2000; Toresson et al., 2000; Kim et al., 2001; Yun et al., 2001). T/x mutants display a similar but less dramatic phenotype (Stenman, 2003). In line with Gsh2 expression in the subpallium, Gsh2 mutants display pallial gene expression in subpallial domains, such as the dLGE (Toresson et al., 2000; Yun et al., 2001). PAX6 is therefore required for the expression of ventral pallium-specific genes, while GSH2 suppresses their expression in the subpallium (Carney et al., 2009).

The organizer function of the antihem is poorly understood compared with that of the cortical hem in hippocampus development (Subramanian et al., 2009). A prominent palisade of radial glial fibers delineates the PSB. These fibers originate in the corticostriatal junction of the VZ and extend up to the pial surface in the piriform cortex (Molnár and Butler, 2002). In the absence of the antihem or in both Pax6 and TIx mutants, the radial glial palisade is severely affected at the PSB. Moreover, Pax6 mutants show a higher number of subpallium-derived interneurons in the cortex, suggesting a role of the radial glial palisade in restricting tangential migration of interneurons during development (Chapouton et al., 1999). In addition, while the antihem expresses Wnt signaling inhibitor sFrp2, Wnt7b is expressed in the dLGE adjacent to the antihem (Kim et al., 2001; Assimacopoulos et al., 2003). This restriction of the Wnt signaling to the subpallial side of the PSB instructs the position of the radial glial palisade. The antihem further expresses specific molecules, like the epidermal growth factor family members TGF- $\alpha$, Neuregulin 1 (NRG1) and NRG3, and fibroblast growth factor 7 (Kim et al., 2001; Assimacopoulos et al., 2003). NRG1 has been shown to be essential in the formation and maintenance of the radial glial cells (Anton et al., 1997; Schmid et al., 2003).

\section{Signaling centers and production of different lineages of pioneer Cajal-Retzius cells}

The three organizing centers at the pallial borders are known to be the main origins of Cajal-Retzius (CR) cells (Takiguchi-Hayashi, 2004; Bielle et al., 2005; Yoshida, 2006; Zhao et al., 2006). These early-born pallial cells differentiate between E10.5 and E12.5 in mice and populate the marginal zones of all cortical areas (Smart and Smart, 1977; Wood et al., 1992; Marín-Padilla, 1998). Many CR cells express Em 1 and Tbr 1 pallial transcription factors (Gorski et al., 2002; Hevner et al., 2003), and Reelin, a secreted glycoprotein that guides radial migration of neocortical neurons (Caviness, 1982; Howell et al., 1997; Alcántara et al., 1998). All CR cells express Reelin, but only hem lineage-derived CR cells express the tumor protein 73 (p73), while antihem- or septumderived CR cells specifically express $D b x 1$. This diversity of CR cell lineages may play a role in the development of cytoarchitectonic differences between the neocortex, the olfactory cortex, and the hippocampus (Bielle et al., 2005).

\section{Migration and layer formation}

\section{Migration and layer formation in the neocortex}

Neuron migration in the neocortex has been well studied. From E11, the first neuroblasts accumulate superficially in the neocortical neuroepithelium, forming the preplate beneath the CR cell layer (Marin-Padilla, 1978; Stewart and Pearlman, 1987; Narboux-Nême and Gaspar, 2008; Vitalis and Rossier, 2011). The preplate is a transitory developmental structure in the neocortex of mouse embryos. Axons of preplate neurons are thought to play the role of pioneers for the development of several fiber tracts (Supèr et al., 1998). From E13, new excitatory neurons settle the preplate, dividing it in two layers, the marginal zone at the surface and the subplate near the VZ. Simultaneously, the radial glia develops and its processes reach the pial surface (Rakic, 2003; Borrell and Götz, 2014). These radial glia processes allow the subsequent migration of neuroblasts, which invade the cortical plate in between the marginal zone and the subplate from E13 to E16 (Marin-Padilla, 1978; De Carlos and O'Leary, 1992). Excitatory neurons of cortical layers are then produced in an inside-out manner from the deep to the superficial layers, such that late-born neurons migrate throughout early-born neurons (Molyneaux et al., 2007; Rakic et al., 2009). Interneurons of the neocortex are produced in the ganglionic eminences of the subpallium [medial ganglionic eminence (MGE), LGE, and caudal ganglionic eminence; Anderson et al., 1997] and migrate first tangentially and then radially to settle the cortical layers, starting from E13 (see Fig. 2; Marín and Rubenstein, 2001; Métin et al., 2006; Gelman et al., 2011). MGE-derived interneurons born at different stages settle distinct layers of the neocortex (Miyoshi and Fishell, 2011).

\section{Early migration to the olfactory cortex}

In contrast to the neocortex, the olfactory cortex is located ventrolaterally and therefore does not line the pallial VZ. Complex waves of cell migration from various regions of the $\mathrm{VZ}$ toward the olfactory cortex have been described in early mouse development, from E9.75 to E12 (Nomura et al., 2006; Garcia-Moreno et al., 2008). Olfactory neurons generated in the dorsal part of the telencephalon at E9.75 migrate ventrally and align the PSB through Ephrin-A5 repulsive activity, which expression is regulated by PAX6 transcription factor. These ventrally migrating neurons differentiate both in lot cells and olfactory cortex neurons (Nomura et al., 2006).

Lot cells are a specific subpopulation of Reelin ${ }^{+} / \mathrm{p} 73^{+}$ CR cells born from E9.5 to E11.5, which were named after their specific expression of lot 1 ( $m$ GluR1 $\beta$; note that lot cells are distinguished from LOT axons by small and capital letters, respectively; Sato et al., 1998; Jiménez et al., 2002; Dixit et al., 2014). Proneural genes Neurogenin1 and Neurogenin2 are coexpressed in dorsal and ventral pallial progenitors and required for the differentiation of lot cells (Dixit et al., 2014). These cells are produced in the whole VZ of the pallium from E9.5 to E11.5 and next migrate tangentially and ventrally toward the cortex surface to organize themselves around the presumptive territory of the LOT at E12.5 (Tomioka et al., 


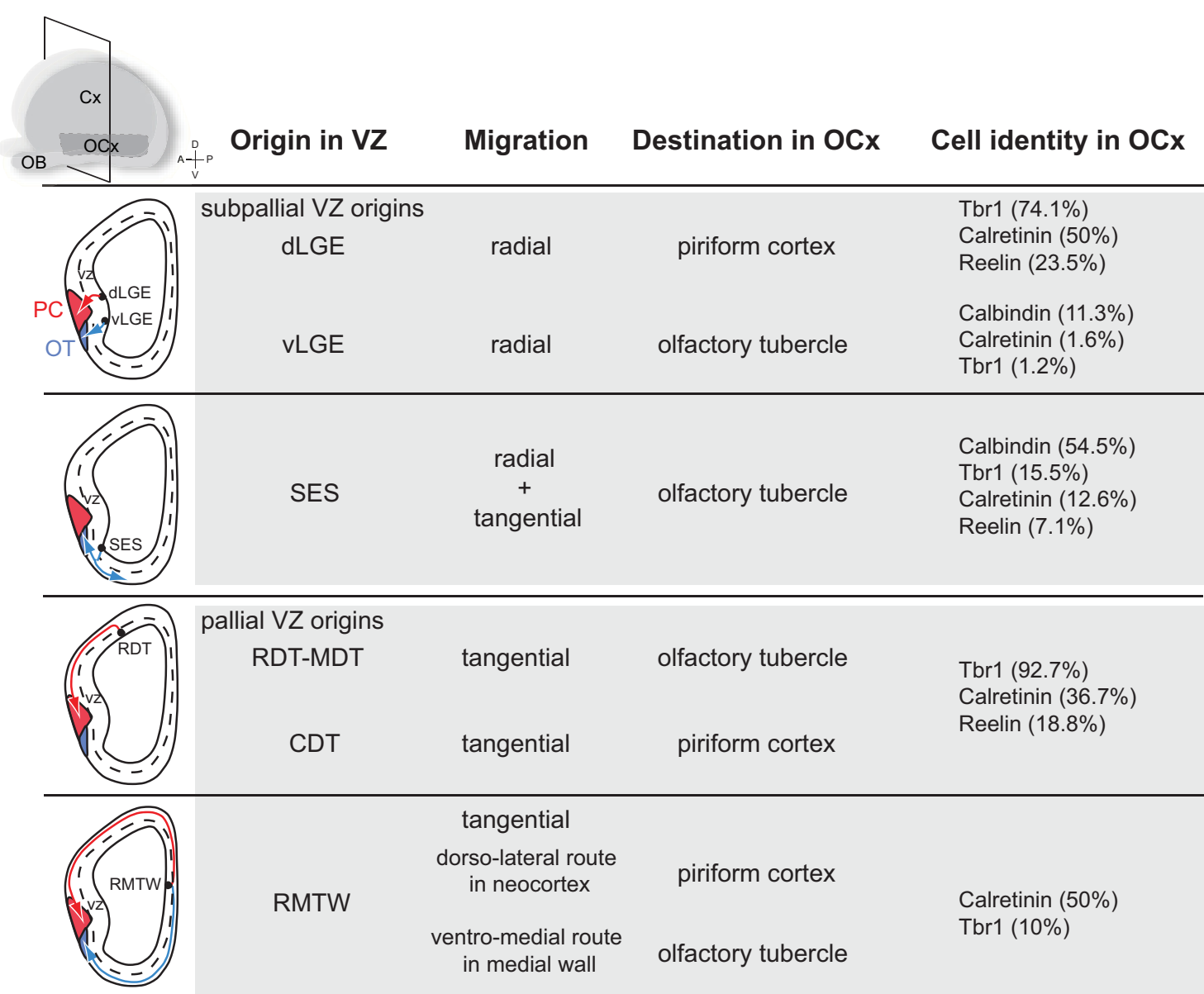

Figure 1. Early migration routes to the olfactory cortex (E10-E12). OCx, Olfactory cortex; PC, piriform cortex; OT, olfactory tubercle; vLGE, ventrolateral ganglionic eminence; SES, septoeminential sulcus; RDT, rostromedial telencephalon; MDT, mediodorsal telencephalon; CDT, caudodorsal telencephalon; RMTW, rostromedial telencephalic wall. In blue, OT migrating neurons; in red, PC migrating neurons. Adapted from Garcia-Moreno et al., 2008, with permission.

2000). The migration and position of lot cells rely on the expression of guidance cues. The neocortex displays dorsoventral gradients of cues, which position the first steps of lot cell migration. The subpallium expresses repulsive cues, which prevent lot cells from invading ventral territories and maintain them superficially at the PSB. Among these cues, Netrin-1 has been shown to locally attract lot cells around the PSB, while Semaphorin 3F is secreted by deep regions of the ventral telencephalon and keeps lot cells at the cerebral surface by its repulsive action (Kawasaki, 2006; Ito et al., 2008). Lot cells act as guideposts for the establishment and positioning of LOT axons, which occur from E12.5 to E13.5 in mice (Squarzoni, 2015). At these early stages, lot cells display long processes and respond to electric stimulation of the OB (Sato et al., 1998; Hirata et al., 2012). Except for lot cells, a general role of CR cells as guideposts for axon development still remains to be elucidated, but CR cells have been involved in the guidance of entorhinal and thalamocortical axons (Ceranik et al., 2000; Del Río et al., 2002; Barber et al., 2015). Recently, de Frutos et al. (2016) discovered a later and unexpected role for lot cells during development: between $\mathrm{E} 13.5$ and E15.5, lot cells retract their processes, adopt a rounded-up morphology with small filopodia, and initiate amoeboid-like migration away from the LOT territory to dorsal neocortical regions (de Frutos et al., 2016). This results in a doubled density of CR cells in the neocortex and a $60 \%$ reduction of lot CR cell density in the LOT territory. This reallocation of lot CR cells is regulated by the NMDA glutamate receptor and is required for the proper organization of neocortex layer 1 and for layer $2 / 3$ pyramidal cell apical dendrite morphology and spine density (de Frutos et al., 2016). Since the olfactory cortex predates the emergence of the neocortex in evolution, the lot cell reallocation into the neocortex could reflect an evolutionary co-option of these ancestral guideposts. In the neocortex, CR cells are progressively eliminated by apoptosis and disappear by the end of the second postnatal week (Del Río et al., 1996). It is yet unclear whether lot cells remaining in the olfactory cortex are integrated in the olfactory network or whether they are a transient population as well.

Garcia-Moreno et al. (2008) described other migration maps and destination areas of olfactory cortex cells by Dil injections at E10 to E12 followed by in toto embryo culture for 1 day (Fig. 1). Neuroblasts are produced in the pallial VZ of the dorsal telencephalon and of the rostromedial telencephalic wall, as well as in the subpallial VZ of the lateral ganglionic eminence and of the septoeminential 
A
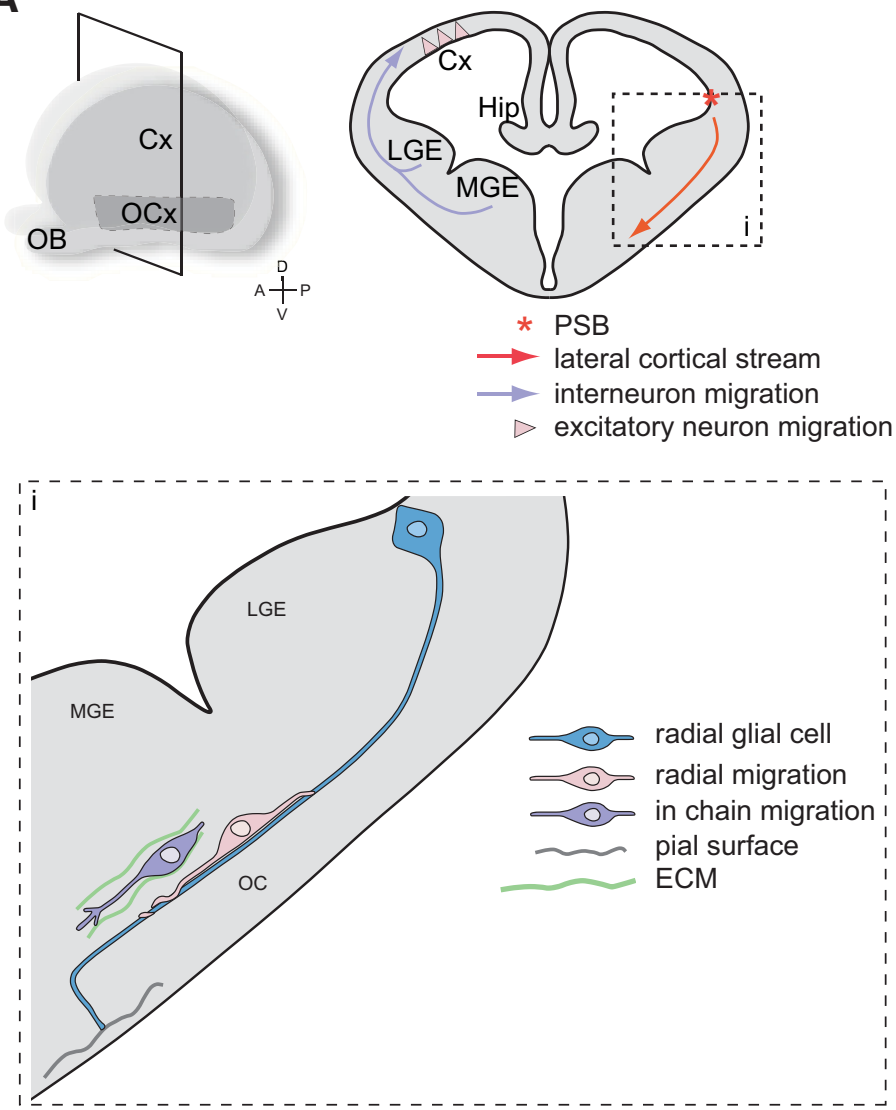

B

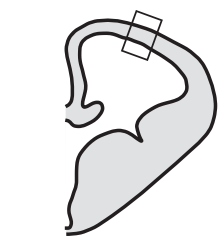

E14.5
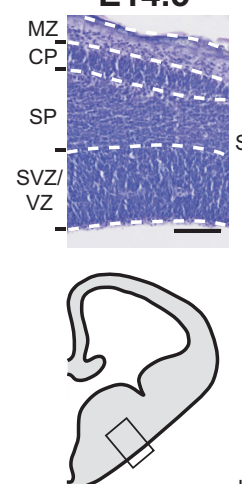

E14.5

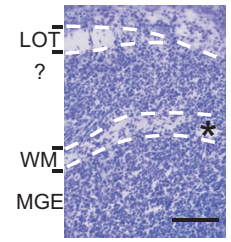

Neocortex

Po

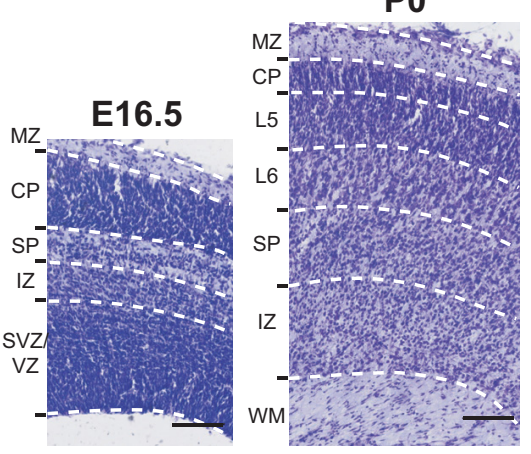

Piriform cortex

Po

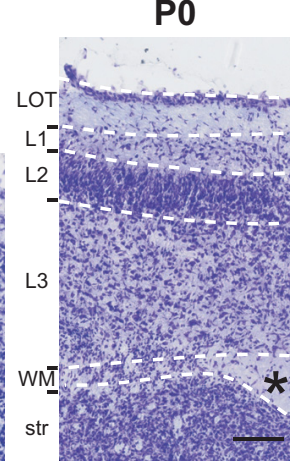

Figure 2. Comparison of developing neocortex and piriform cortex. $\boldsymbol{A}$, Main migratory routes to the neocortex and to the piriform cortex. i, Lateral cortical stream and modes of migration to the piriform cortex. $\boldsymbol{B}$, Prenatal development of layers in the neocortex and in the piriform cortex illustrated by cresyl violet stainings. Cx, neocortex; OCx, olfactory cortex; Hip, hippocampus; ECM, extracellular matrix; MZ, marginal zone; CP, cortical plate; SP, subplate; SVZ, subventricular zone; IZ, intermediate zone; WM, white matter; L, layer; str, striatum; *anterior commissure. Scale bars, $200 \mu \mathrm{m}$.

sulcus. These neuroblasts display tangential or radial migration, with some cells displaying both types of migration sequentially. The authors showed that the cell destination and identity in the olfactory cortex differ depending on their origin in the VZ (Fig. 1). Surprisingly, some neurons from the pallial rostromedial telencephalic wall VZ differentiate in interneurons, while others generated in the dorsal telencephalon differentiate in excitatory neurons. In addition, olfactory cortex neurons from the subpallial dorsal lateral ganglionic eminence VZ differentiate in excitatory neurons, while others generated in the septoeminential sulcus mainly differentiate in interneurons (Garcia-Moreno et al., 2008; Fig. 1). In which olfactory cortex layer these early cells do settle and what are their specific functions in the circuit are not yet elucidated. Further investigations are needed to decipher whether cells coming from different regions in the VZ express specific lineage markers, which could help to identify cell populations and their specific functions within the olfactory cortex.

\section{Late migration routes to the olfactory cortex}

The olfactory cortex neurons born in the lateral and ventral pallium at embryonic stages E12 to E15 in rat embryos (corresponding to E11 to E14 in mice) have been initially described to migrate radially toward the surface of the ventrolateral telencephalon (Bayer, 1986; Valverde and Santacana, 1994; De Carlos et al., 1996). The most described migratory route for olfactory cortex neurons is the lateral cortical stream. This migratory route is formed by cells migrating to the piriform cortex, the olfactory tubercle, and the olfactory amygdala. Neuroblasts taking this route are born in the VZ at the PSB and migrate tangentially to the brain surface through ventral regions of the telencephalon, and then radially to settle in the piriform cortex (Fig. 2). In Pax6 mutant mice (which display an impaired PSB formation), the routing of the lateral cortical stream toward the amygdala and the olfactory cortex is altered (Chapouton et al., 1999; Tole, 2005). In contrast to other known tangential migratory streams described for interneuron migration, the neuroblasts of the lateral cortical stream mainly differentiate into excitatory neurons in the piriform cortex (Corbin et al., 2001). Bai et al. (2008) studied this migratory stream in rat embryos by in utero electroporation of a plasmid, allowing monomeric RFP expression by the cells born at E13 in the VZ at the level of the PSB. After 3 days, the cells migrate tangentially toward ventral regions along the lateral cortical stream. These cells settle the piriform cortex after 6 days and 
mainly differentiate into neuronal transcription factor $\mathrm{TBR}^{+}$cells (Hevner et al., 2001; Bai et al., 2008). However Carney et al. (2006) showed that the identity of cells migrating along the lateral cortical stream is not homogeneous. The authors described two populations of progenies migrating along the lateral cortical stream in mouse embryos: PAX6 ${ }^{+}$progenies, which derive from the pallium; and $\mathrm{DLX} 2^{+}$progenies, which derive from the subpallium. These two populations are generated at precise and distinct temporal windows during development. From E11.5, Pax6 is highly expressed in the pallium and at the $\mathrm{PSB}$ of the VZ. At this stage, some PAX6 ${ }^{+}$cells are visible along the lateral cortical stream and in the piriform cortex. At E15.5, $\mathrm{PAX6}^{+}$cells settle the piriform cortex and the amygdaloid complex. DLX2 ${ }^{+}$cells arose from the PSB about 2 days after PAX6 ${ }^{+}$cells, at E13.5. DLX2 ${ }^{+}$cells are actively migrating from E15.5, and by E18.5 they accumulate in the piriform cortex and the olfactory amygdala. $\mathrm{PAX}^{+}$cells display a migration along $\mathrm{GFAP}^{+}$radial glial processes found between the PSB of the VZ and the pial surface of the ventrolateral telencephalon at E13.5 and E15.5 (Carney et al., 2006; Fig. 2). Paradoxically, these cells display a tangential migration along radial glial processes. Some $\mathrm{DLX} 2^{+}$cells display migration along radial glial processes as well, but "in chain" migration has also been observed in this population (Carney et al., 2006; Fig. 2). The authors hypothesize that $P A X 6^{+}$cells differentiate in excitatory neurons, while DLX2 ${ }^{+}$cells differentiate in inhibitory neurons, since DLX2 ${ }^{+}$cells express the interneuron marker Calbindin (Ghanem et al., 2007).

Zhao et al. (2008) unraveled novel diencephalon-totelencephalon migrations into the septum, but also into the piriform cortex and the amygdala. By genetically labeling the Foxb1 diencephalic lineage, the authors identified labeled cells from the caudal hypothalamus, which migrate into ventral levels of the telencephalon through the continuity between the ventral diencephalon and the telencephalon. This migration occurs after the previously described migratory streams: it starts from E15.5 and is substantial at E18.5 in mouse embryos (Zhao et al., 2008). At birth, abundant Foxb1-lineage cells migrated from the thalamic region into the globus pallidus, the amygdala, and the piriform cortex. These cells express interneuron markers: most of Foxb1-lineage cells in the cortex and in the amygdala express glutamate decarboxylase (Zhao et al., 2008). Some Foxb1-lineage cells in the cortex were Calretinin ${ }^{+}$, but none of them expressed Calbindin (Zhao et al., 2008). In rodents, as a rule, cortical interneurons are generated in the ganglionic eminences (Marín and Rubenstein, 2003). The migratory stream uncovered by Zhao et al. (2008) would, therefore, allow a specific pool of interneurons to settle the olfactory cortex during late embryonic stages. Whether these interneurons settle a specific layer in the olfactory cortex or whether they are homogeneously distributed remain an open question, as does their specific function in the neuronal network.

\section{Layer formation in the olfactory cortex}

Reminiscent of the neocortex layer inside-out development, injections of $\left[{ }^{3} \mathrm{H}\right]$ thymidine in E14 to E22 timed- pregnant female rats showed significantly more earlyborn cells settled in piriform cortex deep layer 3 compared with layer 2 (Bayer, 1986; Valverde and Santacana, 1994). The piriform cortex layer 2 is easily delineable with its high density of pyramidal cell bodies. This layer starts to organize from E16 and is well definable by E18 in mouse embryos (Klingler et al., 2015; Fig. 2). BrdU injections at different mouse development stages and analyses of cell identity at postnatal day 7 showed that cell birth date significantly affects not only the laminar position of cells but also their cellular fate (Sarma et al., 2011). In mice, most layer 2 pyramidal cells are born at E12. E14born cells are less numerous but still differentiate mainly in pyramidal cells. However, E16-born cells display more heterogeneous identities, as follows: $43 \%$ differentiate in pyramidal neurons, $24 \%$ differentiate in nonpyramidal neurons (interneurons), and $33 \%$ differentiate in nonneuronal cells (astrocytes; Sarma et al., 2011). These results show the conservation of a fundamental developmental chronology in both paleocortices and neocortices, with the sequential generation of pyramidal cells, interneurons, and glia. Labeling of cells generated at precise time points during development could be helpful to identify genetic markers of cell populations in the olfactory cortex. So far, nothing is known about the developmental dynamics of layer 3 neurons.

Axons from $\mathrm{OB}$ mitral and tufted cells fasciculate to form the LOT and develop collaterals, which invade the ipsilateral olfactory cortex layer 1 from E15.5 to E17.5 in a caudal to rostral sequence (Fig. 3; Haberly, 1983, 2001; Haberly and Feig, 1983; Hirata and Fujisawa, 1999). Layer 1 can be divided into the following two sublayers: superficial layer 1a formed by the terminals of LOT axons, which make synaptic contacts with the apical dendrites of layer $2 / 3$ pyramidal cells; and layer $1 b$, which is formed by the apical dendrites of layer 2/3 pyramidal cells (Schwob and Price, 1984; Suzuki and Bekkers, 2011; Fig. 3). In the adult mouse brain, layers $1 \mathrm{a}$ and $1 \mathrm{~b}$ are delineable by MAP-2 and Calretinin immunostainings, which label layer 2/3 pyramidal cell dendrites and LOT axons, respectively (Sarma et al., 2011). At birth, layer 1 is not yet subdivided. Layer 1a starts to be distinguishable from postnatal day 7 with visible costaining of MAP-2 and Calretinin (Sarma et al., 2011). These observations suggest that the synaptic contacts between LOT terminals and layer $2 / 3$ pyramidal cell apical dendrites develop during the first postnatal week. During mouse embryonic development, LOT axons develop collaterals, which first invade the CoA at E15.5, then the piriform cortex 1 day later, followed by the more rostrally located regions of the olfactory cortex (Hirata and Fujisawa, 1999). These collaterals allow one LOT axon to make synaptic contacts with layer $2 / 3$ pyramidal cells of different regions of the olfactory cortex (Ojima et al., 1984). Since LOT axons develop after birth, it is rational to assume that the maturation of the circuit is experience dependent, as it has been well described for the primary somatosensory barrel cortex (for review, see Vitali and Jabaudon, 2014). It would be of interest to investigate the consequences of postnatal odorant stimulus depletion in 
A
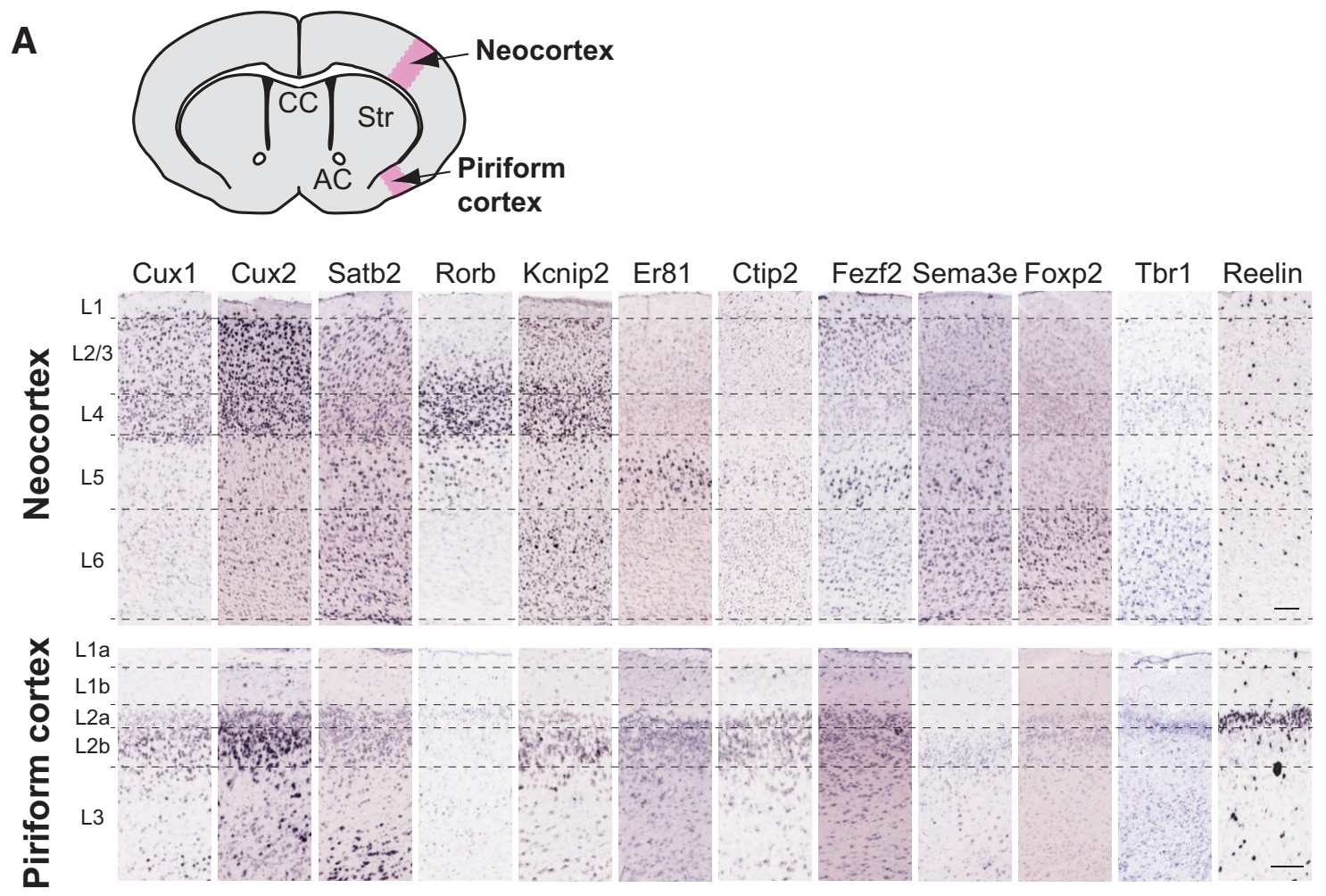

B

Semilunar cells

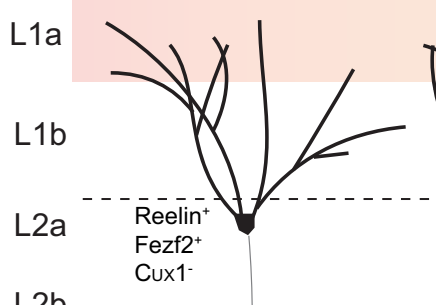

L2b

L3

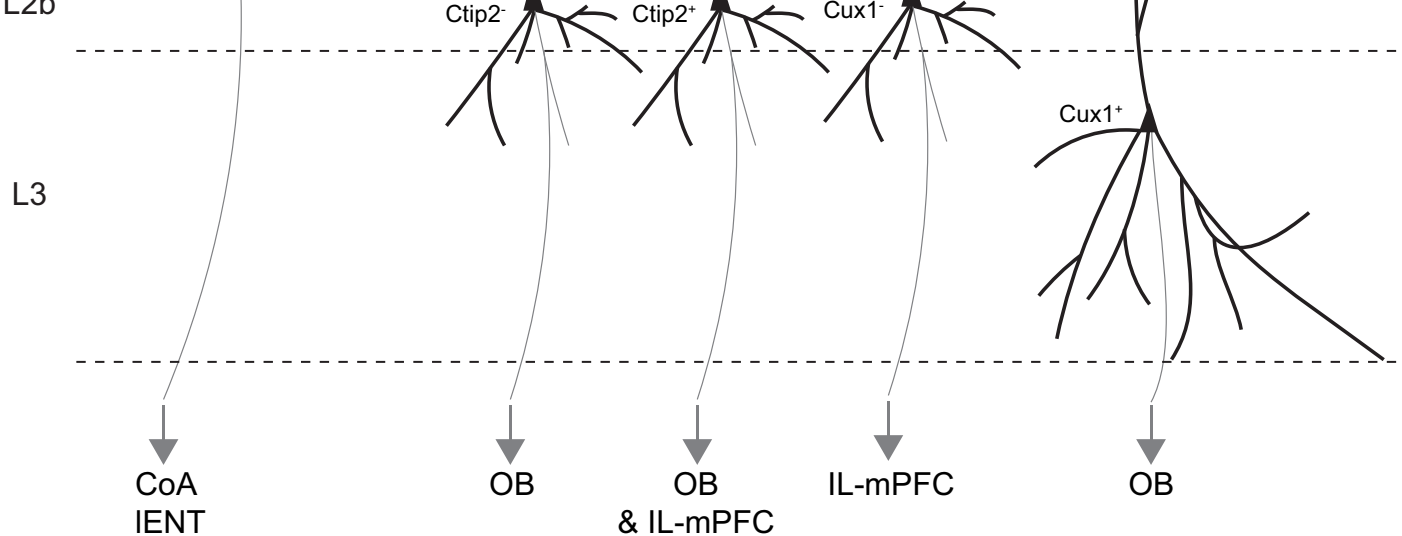

Superficial pyramidal cells
Deep

pyramidal cells

Figure 3. Piriform cortex neuron identities. A, Expression of principal neocortical layer markers in the piriform cortex. In situ hybridizations from Allen Brain Atlas database (postnatal day 56). CC, Corpus callosum; AC, anterior commissure; Str, striatum; L, layer. Scale bar, $200 \mu \mathrm{m}$. B , Organization, molecular identities, and known targets of projection neurons in the piriform cortex. LOT, lateral olfactory tract; CoA, cortical amygdala; IENT, lateral entorhinal cortex; OB, olfactory bulb; IL-mPFC, infralimbic medial prefrontal cortex. 
the organization and maturation of olfactory cortex layer 1 connectivity.

\section{Cell types and organization of the circuit implicated in odor processing}

\section{Cell types and circuit organization within the piriform cortex}

In the piriform cortex, layer 2 pyramidal cells have been initially classified into two populations based on their distinct functions in odor processing: the semilunar and the superficial pyramidal cells (Fig. 3). The semilunar cells are located in the upper part of layer 2 (2a) and display a high spine density in the distal regions of their apical dendrites. These cells receive predominantly afferent excitation from LOT axons, their activity being highly correlated with OB stimulation (Suzuki and Bekkers, 2011). The superficial pyramidal cells are located deeper in layer 2 (2b) and display basal dendrites extending into layer 3 (Fig. 3). They receive weaker afferent inputs from the OB and stronger intracortical excitatory drive through associative fibers, their activity therefore depending on local feedback loops (Haberly and Feig, 1983; Suzuki and Bekkers, 2011; Wiegand et al., 2011; Hagiwara et al., 2012; Fig. 3). Layer 3 is less dense in cell bodies compared with layer 2 and is composed of deep pyramidal cells, which receive minimal afferent inputs from LOT axons, but substantial intracortical excitation (Fig. 3).

To date, molecular identity of the distinct pyramidal neuron within the piriform cortex has been underinvestigated. Most markers defining layers in the neocortex are expressed in the piriform cortex as well (Molyneaux et al., 2007; Fig. 3). Upper layer markers CUX1 and CUX2 (Cubelos et al., 2010) are enriched in piriform cortex layer 2b. Some CUX2 ${ }^{+}$cells are also present in layer 3 . Callosal projection neuron marker SATB2 (Alcamo et al., 2008; Leone et al., 2015) is expressed in piriform cortex layers 2 and 3. It would be of interest to know whether SATB2 ${ }^{+}$ piriform cortex neurons project to the contralateral hemisphere through the anterior commissure and are therefore the counterparts of SATB2 ${ }^{+}$neocortical callosal projection neurons. Thalamic recipient layer 4 neuron marker ROR $\beta$ (Jabaudon et al., 2012) shows very weak expression in the piriform cortex. This could be associated with the fact that piriform cortex neurons do not receive sensory input from the thalamus but directly from the OBs. FEZF2 known to be enriched in neocortex layer 5 (Rouaux and Arlotta, 2010; De la Rossa et al., 2013), is enriched in piriform cortex layer 2a (Diodato et al., 2016). Layer 5/6 marker CTIP2 is expressed in piriform cortex layer 2 (Fig. 3). Gene expression comparison between the neocortex and the piriform cortex has been extensively analyzed in the study by Luzzati (2015). He showed that the neocortex layers $2 / 3$ share $42 \%$ of enriched genes with the piriform cortex, while deep layers 4 and 6 are less related to the piriform cortex with only $29 \%$ of coexpressed genes (Luzzati, 2015). Piriform cortex neurons seem therefore to express common molecular markers enriched in neocortical neurons, but they do not display the same organization within layers. Ramsden et al. (2015) developed a new computational pipeline for high-throughput analysis and comparison of Allen Brain Atlas in situ hybridizations at laminar resolution to study gene expression in the medial entorhinal cortex (MEC). As observed for the piriform cortex, very few genes are uniquely expressed in the medial entorhinal cortex. In addition and contrary to the piriform cortex, deep layers of the medial entorhinal cortex are relatively similar to those of the neocortex, while superficial layers are substantially more divergent at a molecular level (Ramsden et al., 2015). The authors proposed that the medial entorhinal cortex is a type of periarchicortex (paleocortex), a transitional structure between the six-layered neocortex and the three-layered archicortex (Ramsden et al., 2015).

A recent study by Diodato et al. (2016) addressed for the first time the molecular identities of piriform cortex projection neurons using laser capture microdissection of piriform cortex layers and RNA deep sequencing to identify genes differentially expressed within piriform cortex layers in combination with retrograde labeling from piriform cortex targets. With these approaches, they showed that layer 2a semilunar cells project to CoA and IENT and express Reelin and Fezf2 (Fig. 3). The expression of Reelin by excitatory projection neurons in adult brain is specific to the piriform cortex, since in the neocortex, Reelin is mostly expressed by interneurons (Alcántara et al., 1998; Pesold et al., 1998; Ramos-Moreno et al., 2006). These Reelin $^{+}$piriform cortex semilunar cells resemble the CR cells from the developing brain (Carceller et al., 2016). Carceller et al. (2016) proposed that the secretion of Reelin by upper piriform cortex layer 2 could participate in the maturation of an immature neuron subpopulation expressing polysialylated-neural cell adhesion molecule and Doublecortin located deeper in layer 2 (Nacher et al., 2001; Luzzati et al., 2009; Klempin et al., 2011). Interestingly, Reelin ${ }^{+}$stellate principal cells have been described in the adult MEC layer 2 (Varga et al., 2010). The MEC layer 2 also comprises pyramidal cells, some of which express Doublecortin late in postnatal development (Ray and Brecht, 2016). A role for Reelin in the late maturation of immature neuron subpopulations can therefore also be considered in the case of the MEC.

Besides, piriform cortex pyramidal neurons sending projections back to $\mathrm{OB}$ are located in layer $2 \mathrm{~b}$ and layer 3 , display morphology characteristics of superficial and deep pyramidal cells, and express Cux1 (Fig. 3). Interestingly, 3D reconstruction of feedback-projecting neurons after rabies virus injection in the granule cell layer of the main OB showed that these cells are more numerous in the anterior than in the posterior piriform cortex and display a nonrandom organization: piriform cortex neurons next to one another project to similar regions of the $\mathrm{OB}$ granule cell layer (Padmanabhan et al., 2016). Neurons projecting to IL subdivision of the medial prefrontal cortex (IL-mPFC) are mainly located in layer $2 \mathrm{~b}$ and express Ctip2. Moreover, a fraction of layer $2 b$ neurons express both Cux1 and Ctip2 and project to both OB and IL-mPFC (Fig. 3; Diodato et al., 2016). This study points out interesting differences about the molecular organizations of the piriform cortex and the neocortex: while in the neocortex, Cux 1 is expressed by superficial layer neurons, 
and Fezf2 by deep layer $5 / 6$ neurons exclusively; this organization is reversed in the piriform cortex, where Fezf2 is expressed in layer $2 \mathrm{a}$, and Cux 1 in layers $2 \mathrm{~b}$ and 3. Moreover, Cux1 and Ctip2 are expressed in mutually exclusive populations in the neocortex, while a fraction of layer $2 \mathrm{~b}$ neurons express both markers in the piriform cortex. Interestingly, the authors further showed that in Reelin-deficient mice, where cells of distinct layers are intermingled across the piriform cortex, the molecular identities of neurons projecting to the OB $\left(\mathrm{CUX} 1^{+} /\right.$ $\mathrm{FEZF}^{-}$) compared with neurons projecting to the CoA $\left(\mathrm{CUX} 1^{-} / \mathrm{FEZF2}^{+}\right)$are conserved, despite their position defect, as described in the neocortex (Ogawa et al., 1995; Hevner et al., 2003; Wagener et al., 2010; Boyle et al., 2011; Diodato et al., 2016).

\section{Odor processing in the piriform cortex}

In mice, each olfactory sensory neuron in the olfactory epithelium expresses only one olfactory receptor gene, and olfactory sensory neurons expressing a common olfactory receptor send convergent projections to two glomeruli in the main OB (Buck and Axel, 1991; Mombaerts et al., 1996; Malnic et al., 1999, 2010). Despite the precise odotopic organization at these levels of the olfactory circuit, individual odorants evoke a response in sparsely and randomly distributed sets of neurons within the piriform cortex (Rennaker et al., 2007; Poo and Isaacson, 2009; Stettler and Axel, 2009; Ghosh et al., 2011; Miyamichi et al., 2011; Sosulski et al., 2011). Using singlecell recordings from head-restrained awake mice, Zhan and Luo (2010) analyzed odor response profiles of individual neurons in the anterior piriform cortex. Upon odorant presentation, $25 \%$ of projection neurons were broadly excited and rarely inhibited, $25 \%$ showed no excitation and a clear inhibition, and $50 \%$ displayed very selective responses in terms of excitation and inhibition (Zhan and Luo, 2010). The apparent random connections from the $\mathrm{OB}$ mitral and tufted cell axons to the piriform cortex suggest that the representations of odors in the olfactory cortex are learned by experience. The piriform cortex would detect odors by comparing them with a previously acquired library of odors (Sullivan and Wilson, 2003) and build odor units from the chemicals identified upstream in the olfactory circuit (Johnson et al., 2000). The piriform cortex can therefore be seen as a memory tool optimized in the storage of odor synaptic representations (Barkai et al., 1994).

Olfactory representations within the piriform cortex are strongly shaped by recurrent excitatory and inhibitory intracortical connections (Franks et al., 2011; Poo and Isaacson, 2011). While each piriform cortex pyramidal cell receives only 200 inputs from mitral/tufted OB cells, it receives at least 2000 recurrent excitatory inputs (Davison and Ehlers, 2011; Franks et al., 2011). Contrary to the primary visual and somatosensory cortices, recurrent piriform cortex axons form synapses with the same probability, whatever the distance from the soma (Franks et al., 2011). Local cortical application of baclofen, a $\mathrm{GABA}_{\mathrm{B}}$ antagonist, abolishes intracortical associational transmission from excitatory neurons without affecting LOT- evoked excitatory responses (Tang and Hasselmo, 1994; Franks and Isaacson, 2005). Using this pharmacologic approach, Poo and Isaacson (2011) showed that the recruitment of intracortical input, rather than $O B$ input, largely determines the strength of odor-evoked excitatory synaptic transmission in the piriform cortex. Using a novel transgenic mouse model allowing the expression of channel rhodopsin (ChR2) in a subset of semilunar cells, Choy et al. (2015) showed that ChR2-expressing semilunar cells avoid targeting neighboring semilunar cells but provide strong monosynaptic associational excitation of superficial and deep pyramidal cells. Piriform cortex interneurons also play an important role in odor processing. They allow increasing discrimination of an odor and prevent nonspecific excitations. Only $10 \%$ of neurons will be activated by a given odor (Rennaker et al., 2007; Poo and Isaacson, 2009; Zhan and Luo, 2010). This signal transformation may allow the piriform cortex to perceive a complex mix of odors as an odorant object separated from its pure components. Feedforward inhibition is mediated by layer 1 horizontal and neurogliaform interneurons, which receive direct inputs from the LOT and synapse onto apical dendrites of pyramidal cells, and are thought to play a prominent role in dendritic integration of afferent input from LOT axons in all piriform cortex excitatory cells. Feedback inhibition is mediated by layer $2 / 3$ bitufted regular spiking interneurons, which receive little direct LOT input and synapse onto pyramidal cell bodies and basal dendrites, with deep pyramidal cells receiving the strongest recurrent inhibition (Stokes and Isaacson, 2010; Suzuki and Bekkers, 2010a,b; Taniguchi, 2014; Large et al., 2016). Semilunar cells have been shown to directly activate layer 3 GABAergic interneurons (fast spiking, regular spiking, and neurogliaform), but neither neurogliaform nor horizontal interneurons of layer 1a (Choy et al., 2015). The feedback inhibition would dominate the feedforward inhibition in controlling the activation of piriform pyramidal cells (Franks et al., 2011).

\section{Synaptic organization of the cortex: from 3 to 6 layers}

The cortical type microcircuit consists of a superficial plexiform layer 1 , where extrinsic and intrinsic projections meet the apical dendrites of pyramidal neurons located in deeper layers, and is responsible for the generation of recurrent excitation and inhibition (Haberly, 1990). The neocortex shares the basic microcircuits with the threelayered allocortex, but displays a higher number of neurons and layers (Shepherd, 2011; Fournier et al., 2015). The neocortex could then be described as a double allocortex: two couples of pyramidal cell populations, formed by upper layers $2 / 3$ and deeper layers 5/6, are each located below plexiform layers 1 and 4, respectively, carrying extrinsic inputs (Shepherd, 2011; Luzzati, 2015). In contrast to the dorsal cortex of reptiles or to the piriform cortex of mammals, where sensory afferents come from the top, in the neocortex the thalamic afferents ascend from the depth and efferents descend through the same layers. Both inputs and outputs have therefore potential access to all cells in every layer (Shepherd, 2011). More- 
over, the generation of superficial and deep layers in the neocortex allows expansion of the combinatorial possibilities for intracortical and subcortical processing (Shepherd, 2011). Neocortex upper layers are evolutionarily the most recent. Interestingly and counterintuitively, piriform cortex neurons express most molecular markers found in these neocortex upper layers. These similarities lead to the hypothesis of an olfactory cortex-based developmental program for the evolution of neocortical layers 2/3 (Luzzati, 2015). The early neocortical column would therefore result of the superposition of the lateral cortex (olfactory cortex) and the dorsal cortex (Luzzati, 2015). Careful studies of piriform cortex cell lineages and neuron molecular identities are needed to understand what specific cell types are found in evolutionary "old" olfactory cortex and neocortex layers.

\section{Concluding remarks}

The olfactory cortex, so-called "simple" cortex in the literature when compared with the six-layered neocortex, is often presented as a general model for cortical sensory processing. However, the molecular identities and the specific functions of cells composing each olfactory cortex layer remain poorly described. The sequential generation of pyramidal cells, interneurons, and glia, as well as the inside-out migration of pyramidal cells seem to be conserved processes in both olfactory cortex and neocortex during development. In the neocortex, excitatory neurons derive from pallial VZ and migrate radially, while inhibitory neurons derive from subpallial VZ and migrate tangentially. This seems not as obvious in the olfactory cortex, where some neurons from the pallium differentiate in inhibitory neurons and some neurons from the subpallium in excitatory neurons (Garcia-Moreno et al., 2008; Fig. 1). The routes of migration toward the olfactory cortex are particularly complicated since olfactory cortex neurons have multiple origins in the VZ and some of them migrate over a long distance to reach their final location. These routes implicate tangential as well as radial migrations. The most studied migratory stream to the olfactory cortex is the lateral cortical stream, which is thought to be the main stream for olfactory cortex excitatory neurons. Some radial glial processes (radial glial palisade) have been identified along this stream and possibly allow the tangential-like migration of excitatory neurons along radial glia (Carney et al., 2006; Fig. 2).

The diversity of their VZ origins implies that the cells composing the olfactory cortex come from different cell lineages and suggests that different cell populations should be definable among olfactory cortex layers. So far, two pyramidal cell populations have mainly been described in the piriform cortex layer 2 based on their morphological and electrophysiological properties (Suzuki and Bekkers, 2011; Fig. 3). However, recent studies started decoding the molecular signatures of projection neurons in respect to their connectivity properties (Diodato et al., 2016; Padmanabhan et al., 2016; Fig. 3). Further investigations will allow understanding whether the different VZ origins and migratory properties of olfactory cortex neurons during development are correlated with their heterogeneous identities and functions in odor processing. Addressing olfactory cortex neuron transcriptional identities throughout development will help to molecularly characterize cell populations with specific properties in the olfactory cortex, in order to compare them with populations identified in the neocortex, in terms of layer localization, connectivity (input and output), and function. The piriform cortex and the dorsal cortex of reptiles (corresponding to visual cortex) both seem to process sensory inputs as high-order cortical areas rather than primary sensory neocortex. Computations performed by high-order cortical areas seem therefore to be ancestral, while computations performed at initial stages of neocortical processing appeared later in evolution, possibly linked to the additions of new layers (Fournier et al., 2015). Unraveling precise neuronal origins and identities in both the neocortex and the olfactory cortex will further elucidate the evolutionarily conserved properties of sensory cortices.

\section{References}

Aboitiz F, Montiel J, Morales D, Concha M (2002) Evolutionary divergence of the reptilian and the mammalian brains: considerations on connectivity and development. Brain Res Rev 39:141153. Medline

Alcamo EA, Chirivella L, Dautzenberg M, Dobreva G, Fariñas I, Grosschedl R, McConnell SK (2008) Satb2 regulates callosal projection neuron identity in the developing cerebral cortex. Neuron 57:364-377. CrossRef Medline

Alcántara S, Ruiz M, D’Arcangelo G, Ezan F, de Lecea L, Curran T, Sotelo C, Soriano E (1998) Regional and cellular patterns of reelin mRNA expression in the forebrain of the developing and adult mouse. J Neurosci 18:7779-7799. Medline

Anderson SA, Eisenstat DD, Shi L, Rubenstein JL (1997) Interneuron migration from basal forebrain to neocortex: dependence on DIx genes. Science 278:474-476. Medline

Anton ES, Marchionni MA, Lee KF, Rakic P (1997) Role of GGF/ neuregulin signaling in interactions between migrating neurons and radial glia in the developing cerebral cortex. Development 124:3501-3510. Medline

Arai Y, Pierani A (2014) Development and evolution of cortical fields. Neurosc Res 86:66-76. CrossRef Medline

Assimacopoulos S, Grove EA, Ragsdale CW (2003) Identification of a Pax6-dependent epidermal growth factor family signaling source at the lateral edge of the embryonic cerebral cortex. J Neurosci 23:6399-6403. Medline

Bai J, Ramos RL, Paramasivam M, Siddiqi F, Ackman JB, LoTurco JJ (2008) The role of DCX and LIS1 in migration through the lateral cortical stream of developing forebrain. Dev Neurosci 30:144-156. CrossRef Medline

Barber M, Arai $Y$, Morishita $Y$, Vigier L, Causeret F, Borello U, Ledonne F, Coppola E, Contremoulins V, Pfrieger FW, Tissir F, Govindan S, Jabaudon D, Proux-Gillardeaux V, Galli T, Pierani A (2015) Migration speed of Cajal-Retzius cells modulated by vesicular trafficking controls the size of higher-order cortical areas. Curr Biol 25:2466-2478. CrossRef Medline

Barkai E, Bergman RE, Horwitz G, Hasselmo ME (1994) Modulation of associative memory function in a biophysical simulation of rat piriform cortex. J Neurophysiol 72:659-677. Medline

Bayer SA (1986) Neurogenesis in the rat primary olfactory cortex. Int J Dev Neurosci 4:251-271. Medline

Bekkers JM, Suzuki N (2013) Neurons and circuits for odor processing in the piriform cortex. Trends Neurosci 36:429-438. CrossRef Medline

Bielle F, Griveau A, Narboux-Nême N, Vigneau S, Sigrist M, Arber S, Wassef M, Pierani A (2005) Multiple origins of Cajal-Retzius cells at 
the borders of the developing pallium. Nat Neurosci 8:1002-1012. CrossRef Medline

Borrell V, Götz M (2014) Role of radial glial cells in cerebral cortex folding. Curr Opin Neurobiol 27:39-46. CrossRef Medline

Boyle MP, Bernard A, Thompson CL, Ng L, Boe A, Mortrud M, Hawrylycz MJ, Jones AR, Hevner RF, Lein ES (2011) Cell-typespecific consequences of reelin deficiency in the mouse neocortex, hippocampus, and amygdala. J Comp Neurol 519:2061-2089. CrossRef Medline

Brunjes PC, Illig KR, Meyer EA (2005) A field guide to the anterior olfactory nucleus (cortex). Brain Res Reviews 50:305-335. CrossRef Medline

Buck L, Axel R (1991) A novel multigene family may encode odorant receptors: a molecular basis for odor recognition. Cell 65:175-187. Medline

Bulchand S, Grove EA, Porter FD, Tole S (2001) LIM-homeodomain gene Lhx2 regulates the formation of the cortical hem. Mech Dev 100:165-175. Medline

Carceller H, Rovira-Esteban L, Nacher J, Castrén E, Guirado R (2016) Neurochemical phenotype of Reelin immunoreactive cells in the piriform cortex layer II. Front Cell Neurosci 10:65. CrossRef Medline

Carney RSE, Alfonso TB, Cohen D, Dai H, Nery S, Stoica B, Slotkin J, Bregman BS, Fishell G, Corbin JG (2006) Cell migration along the lateral cortical stream to the developing basal telencephalic limbic system. J Neurosci 26:11562-11574. CrossRef

Carney RSE, Cocas LA, Hirata T, Mansfield K, Corbin JG (2009) Differential regulation of telencephalic pallial-subpallial boundary patterning by Pax6 and Gsh2. Cereb Cortex 19:745-759. CrossRef

Caviness VS (1982) Neocortical histogenesis in normal and reeler mice: a developmental study based upon [3H]thymidine autoradiography. Brain Res 256:293-302. CrossRef

Ceranik K, Zhao S, Frotscher M (2000) Development of the entorhino-hippocampal projection: guidance by Cajal-Retzius cell axons. Ann N Y Acad Sci 911:43-54. Medline

Chapouton P, Gärtner A, Götz M (1999) The role of Pax6 in restricting cell migration between developing cortex and basal ganglia. Development 126:5569-5579.

Choy JMC, Suzuki N, Shima Y, Budisantoso T, Nelson SB, Bekkers JM (2015) Optogenetic mapping of intracortical circuits originating from semilunar cells in the piriform cortex. Cereb Cortex. Advance online publication. Retrieved January 22, 2017. CrossRef

Cocas LA, Georgala PA, Mangin JM, Clegg JM, Kessaris N, Haydar TF, Gallo V, Price DJ, Corbin JG (2011) Pax6 is required at the telencephalic pallial-subpallial boundary for the generation of neuronal diversity in the postnatal limbic system. J Neurosci 31:53135324. CrossRef Medline

Corbin JG, Nery S, Fishell G (2001) Telencephalic cells take a tangent: non-radial migration in the mammalian forebrain. Nat Neurosci 4[4 Suppl]:1177-1182. CrossRef

Cubelos B, Sebastián-Serrano A, Beccari L, Calcagnotto ME, Cisneros E, Kim S, Dopazo A, Alvarez-Dolado M, Redondo JM, Bovolenta P, Walsh CA, Nieto M (2010) Cux1 and Cux2 regulate dendritic branching, spine morphology, and synapses of the upper layer neurons of the cortex. Neuron 66:523-535. CrossRef Medline

Davison IG, Ehlers MD (2011) Neural circuit mechanisms for pattern detection and feature combination in olfactory cortex. Neuron 70:82-94. CrossRef Medline

De Carlos JA, O'Leary DM (1992) Growth and targeting of subplate axons and establishment of major cortical pathways. J Neurosci 12:1194-1211.

De Carlos JA, López-Mascaraque L, Valverde F (1996) Early olfactory fiber projections and cell migration into the rat telencephalon. Int $\mathrm{J}$ Dev Neurosci 14:853-866. Medline

de Frutos CA, Bouvier G, Arai Y, Thion MS, Lokmane L, Keita M, Garcia-Dominguez M, Charnay P, Hirata T, Riethmacher D, Grove EA, Tissir F, Casado M, Pierani A, Garel S (2016) Reallocation of olfactory Cajal-Retzius cells shapes neocortex architecture. Neuron 92:435-448. CrossRef Medline
Del Río JA, Heimrich B, Supèr H, Borrell V, Frotscher M, Soriano E (1996) Differential survival of Cajal-Retzius cells in organotypic cultures of hippocampus and neocortex. J Neurosci 16:68966907. Medline

del Río JA, Solé M, Borrell V, Martínez A, Soriano E (2002) Involvement of Cajal-Retzius cells in robust and layer-specific regeneration of the entorhino-hippocampal pathways. Eur J Neurosci 15: 1881-1890. Medline

Diodato A, Ruinart de Brimont M, Yim YS, Derian N, Perrin S, Pouch J, Klatzmann D, Garel S, Choi GB, Fleischmann A (2016) Molecular signatures of neural connectivity in the olfactory cortex. Nat Commun 7:12238 CrossRef Medline

De la Rossa A, Bellone C, Golding B, Vitali I, Moss J, Toni N, Lüscher C, Jabaudon D (2013) In vivo reprogramming of circuit connectivity in postmitotic neocortical neurons. Nat Neurosci 16:193-200. CrossRef Medline

Dixit R, Wilkinson G, Cancino Gl, Shaker T, Adnani L, Li S, Dennis D, Kurrasch D, Chan JA, Olson EC, Kaplan DR, Zimmer C, Schuurmans C (2014) Neurog1 and Neurog2 control two waves of neuronal differentiation in the piriform cortex. J Neurosci 34:539-553. CrossRef Medline

Dou CL, Li S, Lai E (1999) Dual role of brain factor-1 in regulating growth and patterning of the cerebral hemispheres. Cereb Cortex 9:543-550. Medline

Ekstrand JJ, Domroese ME, Johnson DMG, Feig SL, Knodel SM, Behan M, Haberly LB (2001) A new subdivision of anterior piriform cortex and associated deep nucleus with novel features of interest for olfaction and epilepsy. J Comp Neurol 434:289-307. Medline

Fournier J, Müller CM, Laurent G (2015) Looking for the roots of cortical sensory computation in three-layered cortices. Curr Opin Neurobiol 31:119-126. CrossRef Medline

Franks KM, Isaacson JS (2005) Synapse-specific downregulation of NMDA receptors by early experience: a critical period for plasticity of sensory input to olfactory cortex. Neuron 47:101-114. CrossRef Medline

Franks KM, Russo MJ, Sosulski DL, Mulligan AA, Siegelbaum SA, Axel R (2011) Recurrent circuitry dynamically shapes the activation of piriform cortex. Neuron 72:49-56. CrossRef Medline

Garcia-Moreno F, Lopez-Mascaraque L, de Carlos JA (2008) Early telencephalic migration topographically converging in the olfactory cortex. Cereb Cortex 18:1239-1252. CrossRef

Gelman D, Griveau A, Dehorter N, Teissier A, Varela C, Pla R, Pierani A, Marín O (2011) A wide diversity of cortical GABAergic interneurons derives from the embryonic preoptic area. $J$ Neurosci 31: 16570-16580. CrossRef Medline

Ghanem N, Yu M, Long J, Hatch G, Rubenstein JLR, Ekker M (2007) Distinct cis-regulatory elements from the DIx1/Dlx2 locus mark different progenitor cell populations in the ganglionic eminences and different subtypes of adult cortical interneurons. J Neurosci 27:5012-5022. CrossRef

Ghosh S, Larson SD, Hefzi H, Marnoy Z, Cutforth T, Dokka K, Baldwin KK (2011) Sensory maps in the olfactory cortex defined by long-range viral tracing of single neurons. Nature 472:217-220. CrossRef Medline

Gorski JA, Talley T, Mengsheng Q, Puelles L, Rubenstein JL, Jones KR (2002) Cortical excitatory neurons and glia, but not GABAergic neurons, are produced in the Emx1-expressing lineage. J Neurosci 22:6309-6314

Haberly LB (1983) Structure of the piriform cortex of the opossum. I. Description of neuron types with golgi methods. J Comp Neurol 213:163-187. CrossRef Medline

Haberly LB (1990) Comparative aspects of olfactory cortex. In: Cerebral cortex (Jones EG, Peters A, eds), pp 137-166. Boston, MA: Springer US.

Haberly LB (2001) Parallel-distributed processing in olfactory cortex: new insights from morphological and physiological analysis of neuronal circuitry. Chem Senses 26:551-576. Medline

Haberly LB, Price JL (1978) Association and commissural fiber systems of the olfactory cortex of the rat. J Comp Neurol 178:711740. CrossRef 
Haberly LB, Feig SL (1983) Structure of the piriform cortex of the opossum. II. Fine structure of cell bodies and neuropil. J Comp Neurol 216:69-88. CrossRef Medline

Hagiwara A, Pal SK, Sato TF, Wienisch M, Murthy VN (2012) Optophysiological analysis of associational circuits in the olfactory cortex. Front Neural Circuits 6:18. CrossRef

Hanashima C, Fernandes M, Hebert JM, Fishell G (2007) The role of Foxg1 and dorsal midline signaling in the generation of CajalRetzius subtypes. J Neurosci 27:11103-11111. CrossRef Medline Hevner RF, Shi L, Justice N, Hsueh YP, Sheng M, Smiga S, Bulfone A, Goffinet AM, Campagnoni AT, Rubenstein JL (2001) Tbr1 regulates differentiation of the preplate and layer 6 . Neuron 353-366. CrossRef

Hevner RF, Neogi T, Englund C, Daza RAM, Fink A (2003) CajalRetzius cells in the mouse: transcription factors, neurotransmitters, and birthdays suggest a pallial origin. Dev Brain Res 141:3953. CrossRef

Hirata T, Fujisawa H (1999) Environmental control of collateral branching and target invasion of mitral cell axons during development. J Neurobiol 38:93-104. Medline

Hirata T, Nomura T, Takagi Y, Sato Y, Tomioka N, Fujisawa H, Osumi $\mathrm{N}$ (2002) Mosaic development of the olfactory cortex with Pax6dependent and -independent components. Dev Brain Res 136:1726.

Hirata T, Kumada T, Kawasaki T, Furukawa T, Aiba A, Conquet F, Saga Y, Fukuda A (2012) Guidepost neurons for the lateral olfactory tract: expression of metabotropic glutamate receptor 1 and innervation by glutamatergic olfactory bulb axons. Dev Neurobiol 72:1559-1576. CrossRef

Howell BW, Hawkes R, Soriano E, Cooper JA (1997) Neuronal position in the developing brain is regulated by mouse disabled-1. Nature 389:733-737.

Isaacson JS (2010) Odor representations in mammalian cortical circuits. Curr Opin Neurobiol 20:328-331. CrossRef Medline

Ito K, Kawasaki T, Takashima S, Matsuda I, Aiba A, Hirata T (2008) Semaphorin $3 \mathrm{~F}$ confines ventral tangential migration of lateral olfactory tract neurons onto the telencephalon surface. J Neurosci 28:4414-4422. CrossRef Medline

Jabaudon D, Shnider SJ, Tischfield DJ, Galazo MJ, Macklis JD (2012) ROR $\beta$ induces barrel-like neuronal clusters in the developing neocortex. Cereb Cortex 22:996-1006. CrossRef Medline

Jiménez D, López-Mascaraque LM, Valverde F, De Carlos JA (2002) Tangential migration in neocortical development. Dev Biol 244: 155-169. CrossRef Medline

Johnson DM, Illig KR, Behan M, Haberly LB (2000) New features of connectivity in piriform cortex visualized by intracellular injection of pyramidal cells suggest that "primary" olfactory cortex functions like "association" cortex in other sensory systems. J Neurosci 20:6974-6982. Medline

Kawasaki T (2006) Netrin 1 regulates ventral tangential migration of guidepost neurons in the lateral olfactory tract. Development 133: 845-853. CrossRef Medline

Kerr KM, Agster KL, Furtak SC, Burwell RD (2007) Functional neuroanatomy of the parahippocampal region: the lateral and medial entorhinal areas. Hippocampus 17:697-708. CrossRef Medline

Kim AS, Anderson SA, Rubenstein JLR, Lowenstein DH, Pleasure SJ (2001) Pax-6 regulates expression of SFRP-2 and Wnt-7b in the developing CNS. J Neurosci 21:RC132.

Klempin F, Kronenberg G, Cheung G, Kettenmann H, Kempermann G (2011) Properties of doublecortin-(DCX)-expressing cells in the piriform cortex compared to the neurogenic dentate gyrus of adult mice. PLoS One 6:e25760. CrossRef Medline

Klingler E, Martin PM, Garcia M, Moreau-Fauvarque C, Falk J, Chareyre F, Giovannini M, Chédotal A, Girault JA, Goutebroze L (2015) The cytoskeleton-associated protein SCHIP1 is involved in axon guidance, and is required for piriform cortex and anterior commissure development. Development 142:2026-2036. CrossRef Medline
Large AM, Vogler NW, Mielo S, Oswald A-MM (2016) Balanced feedforward inhibition and dominant recurrent inhibition in olfactory cortex. Proc Natl Acad Sci U S A 113:2276-2281. CrossRef

Leinwand SG, Chalasani SH (2011) Olfactory networks: from sensation to perception. Curr Opin Genet Dev 21:806-811. CrossRef Medline

Leone DP, Heavner WE, Ferenczi EA, Dobreva G, Huguenard JR, Grosschedl R, McConnell SK (2015) Satb2 regulates the differentiation of both callosal and subcerebral projection neurons in the developing cerebral cortex. Cereb Cortex 25:3406-3419. CrossRef Medline

Luzzati F (2015) A hypothesis for the evolution of the upper layers of the neocortex through co-option of the olfactory cortex developmental program. Front Neurosci 9:162. CrossRef

Luzzati F, Bonfanti L, Fasolo A, Peretto P (2009) DCX and PSANCAM expression identifies a population of neurons preferentially distributed in associative areas of different pallial derivatives and vertebrate species. Cereb Cortex 19:1028-1041. CrossRef

Mallamaci A, Stoykova A (2006) Gene networks controlling early cerebral cortex arealization. Eur J Neurosci 23:847-856. CrossRef Medline

Malnic B, Hirono J, Sato T, Buck LB (1999) Combinatorial receptor codes for odors. Cell 96:713-723. Medline

Malnic B, Gonzalez-Kristeller DC, Gutiyama LM (2010) Odorant receptors. In: The neurobiology of olfaction (Menini A, ed), pp 181202. Boca Raton, FL: CRC.

Mangale VS, Hirokawa KE, Satyaki PRV, Gokulchandran N, Chikbire S, Subramanian L, Shetty AS, Martynoga B, Paul J, Mai MV, Li Y, Flanagan LA, Tole S, Monuki ES (2008) Lhx2 selector activity specifies cortical identity and suppresses hippocampal organizer fate. Science 319:304-309. CrossRef

Marín O, Rubenstein JL (2001) A long, remarkable journey: tangential migration in the telencephalon. Nat Rev Neurosci 2:780-790. CrossRef Medline

Marin-Padilla M (1978) Dual origin of the mammalian neocortex and evolution of the cortical plate. Anat Embryol 152:109-126. Medline

Marín-Padilla M (1998) Cajal-Retzius cells and the development of the neocortex. Trends Neurosci 21:64-71. Medline

Marín O, Rubenstein JLR (2003) Cell migration in the forebrain. Annu Rev Neurosci 26:441-483. CrossRef Medline

Medina L, Legaz I, González G, De Castro F, Rubenstein JLR, Puelles $L$ (2004) Expression of Dbx1, Neurogenin 2, Semaphorin 5A, Cadherin 8, and Emx1 distinguish ventral and lateral pallial histogenetic divisions in the developing mouse claustroamygdaloid complex. J Comp Neurol 474:504-523. CrossRef

Meyer EA, Illig KR, Brunjes PC (2006) Differences in chemo- and cytoarchitectural features within pars principalis of the rat anterior olfactory nucleus suggest functional specialization. J Comp Neurol 498:786-795. CrossRef Medline

Métin C, Baudoin J-P, Rakić S, Parnavelas JG (2006) Cell and molecular mechanisms involved in the migration of cortical interneurons. Eur J Neurosci 23:894-900. CrossRef Medline

Miyamichi K, Amat F, Moussavi F, Wang C, Wickersham I, Wall NR, Taniguchi H, Tasic B, Huang ZJ, He Z, Callaway EM, Horowitz MA, Luo $L$ (2011) Cortical representations of olfactory input by transsynaptic tracing. Nature 472:191-196. CrossRef Medline

Miyoshi G, Fishell G (2011) GABAergic interneuron lineages selectively sort into specific cortical layers during early postnatal development. Cereb Cortex 21:845-852. CrossRef Medline

Molnár Z, Butler AB (2002) The corticostriatal junction: a crucial region for forebrain development and evolution. Bioessays 24: 530-541. CrossRef Medline

Molyneaux BJ, Arlotta P, Menezes JRL, Macklis JD (2007) Neuronal subtype specification in the cerebral cortex. Nat Rev Neurosci 8:427-437. CrossRef Medline

Mombaerts P, Wang F, Dulac C, Chao SK, Nemes A, Mendelsohn M, Edmondson J, Axel R (1996) Visualizing an olfactory sensory map. Cell 87:675-686. Medline

Montiel JF, Aboitiz F (2015) Pallial patterning and the origin of the isocortex. Front Neurosci 9:377. CrossRef 
Monuki ES, Porter FD, Walsh CA (2001) Patterning of the dorsal telencephalon and cerebral cortex by a roof Plate-Lhx2 pathway. Neuron 32:591-604. Medline

Muzio L, Mallamaci A (2005) Foxg1 confines Cajal-Retzius neuronogenesis and hippocampal morphogenesis to the dorsomedial pallium. J Neurosci 25:4435-4441. CrossRef Medline

Nacher J, Crespo C, McEwen BS (2001) Doublecortin expression in the adult rat telencephalon. Eur J Neurosci 14:629-644. Medline

Nakagawa Y, O'Leary DD (2001) Combinatorial expression patterns of LIM-homeodomain and other regulatory genes parcellate developing thalamus. J Neurosci 21:2711-2725.

Narboux-Nême N, Gaspar P (2008) Développement du cortex cérébral: apports récents des études chez la souris et les primates. Èpilepsies 20:220-228.

Noctor SC, Martínez-Cerdeño V, Ivic L, Kriegstein AR (2004) Cortical neurons arise in symmetric and asymmetric division zones and migrate through specific phases. Nat Neurosci 7:136-144. CrossRef Medline

Nomura T, Holmberg J, Frisen J, Osumi N (2006) Pax6-dependent boundary defines alignment of migrating olfactory cortex neurons via the repulsive activity of ephrin A5. Development 133:13351345. CrossRef Medline

O'Leary DDM, Chou S-J, Sahara S (2007) Area patterning of the mammalian cortex. Neuron 56:252-269.

Ogawa M, Miyata T, Nakajima K, Yagyu K, Seike M, Ikenaka K, Yamamoto H, Mikoshiba K (1995) The reeler gene-associated antigen on Cajal-Retzius neurons is a crucial molecule for laminar organization of cortical neurons. Neuron 14:899-912. CrossRef

Ojima H, Mori K, Kishi K (1984) The trajectory of mitral cell axons in the rabbit olfactory cortex revealed by intracellular HRP injection. J Comp Neurol 230:77-87. CrossRef Medline

Padmanabhan K, Osakada F, Tarabrina A, Kizer E, Callaway EM, Gage FH, Sejnowski TJ (2016) Diverse representations of olfactory information in centrifugal feedback projections. J Neurosci 36: 7535-7545. CrossRef Medline

Pesold C, Impagnatiello F, Pisu MG, Uzunov DP, Costa E, Guidotti A, Caruncho HJ (1998) Reelin is preferentially expressed in neurons synthesizing gamma-aminobutyric acid in cortex and hippocampus of adult rats. Proc Natl Acad Sci U S A 95:3221-3226. CrossRef

Piñon MC, Tuoc TC, Ashery-Padan R, Molnár Z, Stoykova A (2008) Altered molecular regionalization and normal thalamocortical connections in cortex-specific Pax6 knock-out mice. J Neurosci 28: 8724-8734. CrossRef Medline

Poo C, Isaacson JS (2009) Odor representations in olfactory cortex: "sparse" coding, global inhibition, and oscillations. Neuron 62: 850-861. CrossRef Medline

Poo C, Isaacson JS (2011) A major role for intracortical circuits in the strength and tuning of odor-evoked excitation in olfactory cortex. Neuron 72:41-48. CrossRef Medline

Puelles L, Kuwana E, Puelles E, Bulfone A, Shimamura K, Keleher J, Smiga S, Rubenstein JLR (2000) Pallial and subpallial derivatives in the embryonic chick and mouse telencephalon, traced by the expression of the genes Dlx-2, Emx-1, Nkx-2.1, Pax-6, and Tbr-1. J Comp Neurol 424:409-438. CrossRef

Rakic P (2003) Developmental and evolutionary adaptations of cortical radial glia. Cereb Cortex 13:541-549.

Rakic P, Ayoub AE, Breunig JJ, Dominguez MH (2009) Decision by division: making cortical maps. Trends Neurosci 32:291-301. CrossRef Medline

Ramos-Moreno T, Galazo MJ, Porrero C, Martínez-Cerdeño V, Clascá $F$ (2006) Extracellular matrix molecules and synaptic plasticity: immunomapping of intracellular and secreted Reelin in the adult rat brain. Eur J Neurosci 23:401-422. CrossRef Medline

Ramsden HL, Sürmeli G, McDonagh SG, Nolan MF (2015) Laminar and dorsoventral molecular organization of the medial entorhinal cortex revealed by large-scale anatomical analysis of gene expression. PLoS Comput Biol 11:e1004032. CrossRef
Ray S, Brecht M (2016) Structural development and dorsoventral maturation of the medial entorhinal cortex. Elife 5:e13343. CrossRef

Rennaker RL, Chen C-FF, Ruyle AM, Sloan AM, Wilson DA (2007) Spatial and temporal distribution of odorant-evoked activity in the piriform cortex. J Neurosci 27:1534-1542. CrossRef Medline

Rouaux C, Arlotta P (2010) Fezf2 directs the differentiation of corticofugal neurons from striatal progenitors in vivo. Nat Neurosci 13:1345-1347. CrossRef Medline

Sanchez-Andrade G, Kendrick KM (2009) The main olfactory system and social learning in mammals. Behav Brain Res 200:323-335. CrossRef Medline

Sarma AA, Richard MB, Greer CA (2011) Developmental dynamics of piriform cortex. Cereb Cortex 21:1231-1245. CrossRef Medline

Sato Y, Hirata T, Ogawa M, Fujisawa H (1998) Requirement for early-generated neurons recognized by monoclonal antibody Lot 1 in the formation of lateral olfactory tract. J Neurosci 18:78007810.

Schmid RS, McGrath B, Berechid BE, Boyles B, Marchionni M, Sestan N, Anton ES (2003) Neuregulin 1-erbB2 signaling is required for the establishment of radial glia and their transformation into astrocytes in cerebral cortex. Proc Natl Acad Sci U S A 100:4251-4256. CrossRef

Schwob JE, Price JL (1984) The development of lamination of afferent fibers to the olfactory cortex in rats, with additional observations in the adult. J Comp Neurol 223:203-222. CrossRef Medline

Shepherd GM (2011) The microcircuit concept applied to cortical evolution: from three-layer to six-layer cortex. Front Neuroanat 5:30. CrossRef

Shibata M, Kurokawa D, Nakao H, Ohmura T, Aizawa S (2008) MicroRNA-9 modulates Cajal-Retzius cell differentiation by suppressing Foxg1 expression in mouse medial pallium. J Neurosci 28:10415-10421. CrossRef Medline

Shipley MT, Adamek GD (1984) the connections of the mouse olfactory bulb: a study using orthograde and retrograde transport of wheat germ agglutinin conjugated to horseradish peroxidase. Brain Res Bull 12:669-688. Medline

Smart I, Smart M (1977) The location of nuclei of different labelling intensities in autoradiographs of the anterior forebrain of postnatial mice injected with $[3 \mathrm{H}]$ thymidine on the eleventh and twelfth days post-conception. J Anat 123:512-525.

Sosulski DL, Lissitsyna Bloom M, Cutforth T, Axel R, Datta SR (2011) Distinct representations of olfactory information in different cortical centres. Nature 472:213-216. CrossRef

Squarzoni P (2015) Neuronal and microglial regulators of cortical wiring: usual and novel guideposts. Front Neurosci 9:248. CrossRef

Stenman J (2003) Tlx and Pax6 co-operate genetically to establish the pallio-subpallial boundary in the embryonic mouse telencephalon. Development 130:1113-1122. Medline

Stettler DD, Axel R (2009) Representations of odor in the piriform cortex. Neuron 63:854-864. CrossRef Medline

Stewart GR, Pearlman AL (1987) Fibronectin-like immunoreactivity in the developing cerebral cortex. J Neurosci 7:3325-3333.

Stokes CCA, Isaacson JS (2010) From dendrite to soma: dynamic routing of inhibition by complementary interneuron microcircuits in olfactory cortex. Neuron 67:452-465. CrossRef Medline

Stoykova A, Fritsch R, Walther C, Gruss P (1996) Forebrain patterning defects in small eye mutant mice. Development 122:34533465. Medline

Stoykova A, Götz M, Gruss P, Price J (1997) Pax6-dependent regulation of adhesive patterning, R-cadherin expression and boundary formation in developing forebrain. Development 124:37653777. Medline

Stoykova A, Treichel D, Hallonet M, Gruss P (2000) Pax6 modulates the dorsoventral patterning of the mammalian telencephalon. $J$ Neurosci 20:8042-8050.

Subramanian L, Remedios R, Shetty A, Tole S (2009) Signals from the edges: the cortical hem and antihem in telencephalic development. Semin Cell Dev Biol 20:712-718. CrossRef Medline 
Sullivan RM, Wilson DA (2003) Molecular biology of early olfactory memory. Learn Mem 10:1-4. CrossRef Medline

Supèr $\mathrm{H}$, Soriano $\mathrm{E}$, Uylings $\mathrm{H}$ (1998) The functions of the preplate in development and evolution of the neocortex and hippocampus. Brain Res Brain Res Rev 27:40-64.

Suzuki N, Bekkers JM (2010a) Inhibitory neurons in the anterior piriform cortex of the mouse: classification using molecular markers. J Comp Neurol 518:1670-1687.

Suzuki N, Bekkers JM (2010b) Distinctive classes of GABAergic interneurons provide layer-specific phasic inhibition in the anterior piriform cortex. Cereb Cortex 20:2971-2984.

Suzuki N, Bekkers JM (2011) Two layers of synaptic processing by principal neurons in piriform cortex. J Neurosci 31:2156-2166. CrossRef Medline

Takiguchi-Hayashi K (2004) Generation of Reelin-positive marginal zone cells from the caudomedial wall of telencephalic vesicles. $J$ Neurosci 24:2286-2295. CrossRef Medline

Tang AC, Hasselmo ME (1994) Selective suppression of intrinsic but not afferent fiber synaptic transmission by baclofen in the piriform (olfactory) cortex. Brain Res 659:75-81. CrossRef

Taniguchi H (2014) Genetic dissection of GABAergic neural circuits in mouse neocortex. Front Cell Neurosci 8:8.

Tole S (2005) Selective requirement of Pax6, but not Emx2, in the specification and development of several nuclei of the amygdaloid complex. J Neurosci 25:2753-2760. CrossRef Medline

Tomioka N, Osumi N, Sato Y, Inoue T, Nakamura S, Fujisawa H, Hirata $T$ (2000) Neocortical origin and tangential migration of guidepost neurons in the lateral olfactory tract. J Neurosci 20:5802-5812.

Toresson H, Potter SS, Campbell K (2000) Genetic control of dorsalventral identity in the telencephalon: opposing roles for Pax6 and Gsh2. Development 127:4361-4371. Medline

Valverde F, Santacana M (1994) Development and early postnatal maturation of the rat primary olfactory cortex. Dev Brain Res 80:96-114. CrossRef

Varga C, Lee SY, Soltesz I (2010) Target-selective GABAergic control of entorhinal cortex output. Nat Neurosci 13:822-824. CrossRef Medline
Vitali I, Jabaudon D (2014) Synaptic biology of barrel cortex circuit assembly. Semin Cell Dev Biol 35:156-164. CrossRef Medline

Vitalis T, Rossier J (2011) New insights into cortical interneurons development and classification: contribution of developmental studies. Dev Neurobiol 71:34-44. CrossRef

Wagener RJ, Dávid C, Zhao S, Haas CA, Staiger JF (2010) The somatosensory cortex of reeler mutant mice shows absent layering but intact formation and behavioral activation of columnar somatotopic maps. J Neurosci 30:15700-15709. CrossRef Medline

Wiegand HF, Beed P, Bendels MHK, Leibold C, Schmitz D, Johenning FW (2011) Complementary sensory and associative microcircuitry in primary olfactory cortex. J Neurosci 31:12149-12158. CrossRef

Wilson RI, Mainen ZF (2006) Early events in olfactory processing. Annu Rev Neurosci 29:163-201.

Wood JG, Martin S, Price DJ (1992) Evidence that the earliest generated cells of the murine cerebral cortex form a transient population in the subplate and marginal zone. Dev Brain Res 66:137-140. CrossRef

Yoshida M (2006) Massive loss of Cajal-Retzius cells does not disrupt neocortical layer order. Development 133:537-545. CrossRef Medline

Yun K, Potter S, Rubenstein JL (2001) Gsh2 and Pax6 play complementary roles in dorsoventral patterning of the mammalian telencephalon. Development 128:193-205. Medline

Zhan C, Luo M (2010) Diverse patterns of odor representation by neurons in the anterior piriform cortex of awake mice. $\mathrm{J}$ Neurosc 30:16662-16672. CrossRef Medline

Zhao C, Guan W, Pleasure SJ (2006) A transgenic marker mouse line labels Cajal-Retzius cells from the cortical hem and thalamocortical axons. Brain Res 1077:48-53. CrossRef Medline

Zhao T, Szabó N, Ma J, Luo L, Zhou X, Alvarez-Bolado G (2008) Genetic mapping of Foxb1-cell lineage shows migration from caudal diencephalon to telencephalon and lateral hypothalamus. Eur $\mathrm{J}$ Neurosci 28:1941-1955. CrossRef Medline 